NBER WORKING PAPER SERIES

\title{
DID IMPORT SUBSTITUTION PROMOTE GROWTH IN THE LATE NINETEENTH CENTURY?
}

\author{
Douglas A. Irwin \\ Working Paper 8751 \\ http://www.nber.org/papers/w8751 \\ NATIONAL BUREAU OF ECONOMIC RESEARCH \\ 1050 Massachusetts Avenue \\ Cambridge, MA 02138 \\ February 2002
}

I thank seminar participants at University College/Trinity in Dublin, the London School of Economics, and the University of Warwick for many helpful comments and suggestions. The views expressed herein are those of the author and not necessarily those of the National Bureau of Economic Research.

(C) 2002 by Douglas A. Irwin. All rights reserved. Short sections of text, not to exceed two paragraphs, may be quoted without explicit permission provided that full credit, including $\mathbb{C}$ notice, is given to the source. 
Did Import Substitution Promote Growth in the Late Nineteenth Century?

Douglas A. Irwin

NBER Working Paper No. 8751

February 2002

JEL No. F1, N7

\begin{abstract}
The positive correlation between import tariffs and economic growth across countries in the late nineteenth century suggests that tariffs may have played a causal role in promoting growth. This paper seeks to determine if high tariffs stimulated growth by shifting resources out of agriculture and into manufacturing. The most rapidly growing countries were indeed those that reduced the share of employment in agriculture. Tariffs in agricultural exporting (importing) countries may have promoted (retarded) this shift, although two high tariff, high growth, agricultural-exporting outliers (Argentina and Canada) experienced export-oriented growth and did not pursue import substitution policies. This raises the question of whether economic growth led to changes in the structure of employment rather than changes in employment leading to economic growth.
\end{abstract}

\author{
Douglas A. Irwin \\ Department of Economics \\ Dartmouth College \\ Hanover, NH 03755 \\ and NBER \\ douglas.irwin@dartmouth.edu
}




\section{Did Import Substitution Promote Growth in the Late Nineteenth Century?}

\section{Introduction}

Although import substitution policies - using trade measures to encourage the domestic production of manufactured goods in place of imports - have gradually lost their shine over the postwar period, their reputation has remained intact for the late nineteenth century. ${ }^{1}$ Many midnineteenth century political economists, such as Friedrich List, advocated the use of protectionist tariffs to promote industrialization in countries that were behind the industrial leader, then the United Kingdom. Subsequent experience - notably the rise of Germany and the United States has been interpreted by many as confirming the wisdom of such policies. ${ }^{2}$ Recent work by O'Rourke (2000) and Clemens and Williamson (2001) has strengthened this impression by confirming the existence of a positive correlation between import tariffs and economic growth across countries from 1875 to 1914.

Although this correlation does not establish a causal relationship between tariffs and growth, it is certainly suggestive of causality. A highly plausible (and oft presumed) explanation for the correlation is that tariffs protected domestic manufacturing industries from foreign competition and thereby helped to promote industrialization, which in turn led to more rapid economic growth. If so, inward-oriented development strategies may be considered a success during this period.

But this explanation remains speculative and open to question in the absence of direct

${ }^{1}$ Krueger (1997) examines how economists's views on import substitution have evolved since the 1950 s.

${ }^{2}$ Referring to this period, Bairoch $(1989$, p. 69) writes: "Grossly oversimplified this can be expressed in the following equations: protectionism $=$ economic growth and expansion of trade; liberalism = stagnation in both." 
evidence that ties the tariffs to growth or industrial expansion. Did tariffs really shift resources into manufacturing when so many were designed to protect agricultural producers in the aftermath of Great Grain Invasion, as examined by O’Rourke (1997)? Did the countries registering the strongest growth during this period, such as Argentina and Canada, also experience the most rapid expansion of manufacturing? The correlation between tariffs and growth in the late nineteenth century is clearly intriguing, but demands further study to pin down the mechanism linking the two.

This paper investigates one channel by which trade policies could have promoted growth: by changing the sectoral distribution of employment. Kuznets's (1971) seminal work on modern economic growth highlighted two regularities: that output per worker in agriculture is significantly lower than in industry and services, and that economic growth is invariably accompanied by a shift of employment from agriculture to industry and services. A key question is whether tariff policies in various countries encouraged or inhibited this shift in the structure of employment and thereby helped to raise output per worker.

The goal of this paper is to explore the broad patterns in the data and to seek evidence on whether tariffs affected economic growth through this channel. Section 2 reexamines the basic correlation between tariffs and growth during this period. Section 3 investigates the role of trade policy in promoting shifts in employment across sectors in ways that might have promoted economic growth. Any cross-country regression evidence presented here is not designed to be definitive or to establish causality, particularly because such regressions are a poor instrument for doing so. Therefore, section 4 briefly looks at specific country experiences to help interpret the findings in section 3 . 
To summarize the main results, the evidence in favor of the import substitution view is weak. The most rapidly growing countries of the period were those that showed the biggest decline in the share of the labor force devoted to agriculture. But evidence that tariffs in agricultural exporting countries accelerated this structural change, while tariffs in countries exporting manufactured goods impeded it, is not strong. For example, the two most rapidly expanding countries of the period - Argentina and Canada - grew not because of import substitution, but because large foreign and domestic investments (particularly in railroads) reinforced their comparative advantage in staples products and facilitated an export boom in those goods. Structural change in employment may have been driven by the rapid export-led growth, rather than the growth resulting from structural change due to tariffs. And although these countries had high tariffs, the import duties may have been designed mainly to raise revenue rather than promote domestic manufacturing.

\section{Reexamining the Tariffs-Growth Relationship}

The basic data for evaluating the relationship between trade policy and economic performance are measures of import tariffs and growth in per capita GDP. (Appendix Table 1 presents most of the data used in this paper.) For GDP, most researchers have used Maddison's (1995) data on per capita GDP expressed in 1990 Geary-Khamis "international" dollars. ${ }^{3}$ This paper uses a sample of every country for which Maddison reports a GDP observation in 1870,

${ }^{3}$ Prados de le Escosura (2000) presents an alternative set of real GDP per capita estimates for up to 22 countries based on projections of 1913 purchasing power parity (PPP). The correlation between the Maddison and Prados growth rates is 0.70 for 1870-1913, and the key results from this paper are not significantly altered by using the Prados data. 
which yields up to 27 countries. Results from 17 advanced "core" countries will also be compared to results from the full 27 country sample that also includes developing "periphery" countries. The core consists of high income countries that were well integrated into the world economy through trade, capital flows, and international migration, and include most of Western Europe as well as Argentina, Australia, Canada, New Zealand, and the United States. The additional ten low-income countries of the periphery are Spain, Portugal, Russia, Japan, China, India, Indonesia, Thailand, Brazil, and Mexico. To focus on long-run economic growth performance, three periods are considered: the entire period from 1870 to 1913, and two subperiods, 1870 to 1890 and 1890 to $1913 .{ }^{4}$

The most frequently used indicator of trade policy for this period is simply the average tariff, calculated by dividing customs revenue by the value of imports. On one dimension, the tariff revenue measure is adequate for the late nineteenth century because other trade policy instruments, such as import quotas, voluntary export restraints, and antidumping duties, were rarely employed. ${ }^{5}$ This measure is a crude indicator of trade policy, however, because it provides

4 Other researchers have used the Maddison data in somewhat different ways. O'Rourke (2000) examines ten high income countries (seven in Western Europe and Australia, Canada, and the United States), while Clemens and Williamson (2001) consider a larger sample of 35 countries (relying on interpolations to expand the sample back to 1875 for some countries). Both authors examined growth in a series of five-year intervals from 1875 to 1914, but some have questioned whether such short time horizons are indicative of long-run economic performance. In their critique of cross-country analyses of trade policy and growth, Rodríguez and Rodrik (2001, pp. 314-315) state that "we are not sure that the regularities revealed by the data over time horizons of five years or less are particularly informative about the relationship between trade policy and long-run economic performance." They propose examining results "with averages constructed over a decade or more," which (along with the constraints inherent in the Maddison data) motivates the approach taken here.

5 As Bairoch (1989, p. 72) observes, "the question of non-tariff barriers to trade, which is an important issue today, was not seen as a problem before 1914" because such barriers were 
no information on the structure of protection across industries or sectors. It is also biased downward in comparison to a true measure because high or prohibitive tariffs raise little or no revenue, although the extent of this bias has never been thoroughly documented. ${ }^{6}$

The average tariff offers a snap-shot of trade policy at one particular instant, but what about the pattern of tariffs over time? Figure 1 presents average tariff rates for several countries from 1870 to 1913 and reveals two sets of countries: those with moderate tariffs in the 5 to 9 percent range and those with high tariffs in the 15 to 40 percent range. The moderate tariff countries (in panel A) are all the countries of Western Europe and others such as India, Indonesia, and Japan. There is some variation in the tariffs early in the period, but after 1890 the tariffs begin to converge around 5 to 9 percent. In most countries, the tariff level is relatively stable and persistent over time. There appear to be few trade policy experiments in which a country moves from having low tariffs to high tariffs, or vice versa. With the exception of Russia, all of the high tariff countries (in panel B) lie outside of Europe, although most have strong European ties.

Figure 2 gives a sense of the unconditional relationship between tariffs and growth by plotting the average tariff in 1870 and the average annual growth in real per capita GDP from 1870 to 1913 . The sample is divided into the 17 core countries and the full sample of 27 core

"extremely rare (but not non-existent)."

${ }^{6}$ For the postwar period, Rodriguez and Rodrik (2001, p. 316) note that "an examination of simple averages of taxes on imports and exports and NTB [non-tariff barrier] coverage ratios leaves us with the impression that these measures in fact do a decent job of rank-ordering countries according to the restrictiveness of their trade regimes." However, Pritchett (1996) finds that many different trade policy indicators are not correlated. Pritchett's caution may apply during this period in that trade policies in France and the United Kingdom were quite different even as their average tariff (revenue) measures were quite similar; see Irwin (1993). 
and periphery countries. For the core countries, the correlation between tariffs and growth is 0.68. Argentina, Canada, and the United States stand out as high tariff, high growth countries; without these three countries, the correlation falls to 0.08 . When the sample is extended to include the periphery, the correlation between tariffs and growth falls to 0.20. As Figure 2 indicates, several periphery countries such as Portugal and Brazil had high tariffs but poor growth performance.

To examine these relationships more formally, Table 1 presents the results from regressing the annual average growth in real per capita GDP on the log of the initial level of per capita GDP and the log of the initial average tariff rate. Column (1) examines the core countries during the entire period and finds a positive and significant relationship between tariffs and growth. The coefficient on the log of the average tariff is 0.23 , implying that a one standard deviation increase in the tariff (from the mean) would increase the average annual growth rate of per capita GDP by 0.21 percentage points, about a 15 percent increase in the average growth rate of core countries during this period. This relationship is somewhat smaller but about the same magnitude as that found by O'Rourke (2000).

In this sample, the most rapidly growing countries tended to have high tariffs, but a causal interpretation is questionable: it is doubtful that the Netherlands could have achieved growth rates equal to those of the New World economies simply by imposing a higher tariff. (Instead, the New World could have had other attributes, such as abundant land and scarce labor, enabling them to grow rapidly.) The coefficient on initial income is negative and significant, implying a tendency for convergence; i.e., that countries with a high initial per capita income (such as Australia) tended to grow more slowly. 
Column (2) expands the sample to include the periphery countries. The coefficient on tariffs falls in magnitude and is no longer statistically significant, as suggested by comparing the two panels of Figure 2. In addition, the coefficient on initial per capita income is now positive and significant, indicating that high income countries tended to grow faster than low income countries. Divergence and not convergence of income appears to be the norm in this broader sample of countries. ${ }^{7}$

The remaining columns of Table 1 repeat these regressions for the two sub-periods. For the 1870 to 1890 period, the relationship between tariffs and growth is not statistically significant for the core countries or the full sample. For the 1890 to 1913 period, the tariff variable is statistically significant in both samples. In both periods, there is evidence of convergence among the core countries but divergence more generally.

These basic regressions confirm that there is a positive relationship between tariffs and growth, although the strength of this association varies somewhat depending upon the sample set and time period. Unfortunately, pushing the econometric analysis much beyond this point becomes problematic. The data limitations are severe and there are few other control variables that exist for anything more than just a handful of countries. ${ }^{8}$ As the empirical growth literature

7 This mirrors the more recent finding of long-run convergence among high income OECD countries (Baumol 1986), a lack of convergence among a broader sample of countries (De Long 1988), and divergence more generally (Pritchett 1997). On the forces for convergence in the late nineteenth century, see Taylor (1999).

8 O'Rourke (2000) and Clemens and Williamson (2001) explore whether changes in the capital-labor ratio (measured by coal consumption per worker) and the land-labor ratio affect the tariff-growth relationship, and the general answer is no. But during a period characterized by a high degree of capital and labor mobility between countries (as O'Rourke and Williamson 1999 highlight), factors such as capital investment or population growth are apt to be endogenous and not exogenous determinants of growth, making any interpretation difficult. 
has matured, however, the focus has shifted from the proximate economic determinants of growth (such as investment or schooling) to the institutional preconditions for growth. Knack and Keifer (1995) and numerous subsequent papers point out the importance of institutions meaning the security of property rights, the enforcement of contracts, the absence of government corruption, etc. - as fundamental factors behind growth.

A proxy for political institutions in the late nineteenth century can be found in Marshall and Jaggers (2000) annual "polity" variable. This composite of democracy and autocracy indicators attempts to reflect the degree of competitive political participation and constraints on the exercise of power by the executive. The polity variable ranges from -10 (strongly autocratic) to +10 (strongly democratic). While this variable does not directly measure economic freedom or the protection of property rights, open and competitive political regimes are more likely to operate under the rule of law, have accountable governance systems that limit corruption, and have economies based largely on market-oriented private sector activity. At the same time, the polity variable imperfectly captures those institutional arrangements because direct political participation is not required to guarantee the security of property rights and the freedom to engage in commercial activities.

Figure 3 depicts the unconditional relationship between polity and economic growth and shows a slight tendency for countries with more open political systems in 1870 to experience more rapid growth (the correlation coefficient is 0.37 ). ${ }^{9}$ Table 2 considers the relationship between political institutions and growth performance. The first two columns examine the

9 The late nineteenth century was a period of political stability and there are few regime transitions during this period. 
period from 1870 to 1913 and indicate that, at least for the core countries, more democratic political institutions are associated with better growth performance. The coefficient on tariffs falls slightly in magnitude but is still statistically significant. Columns (3) and (4) suggest that political institutions are better suited than tariffs to explaining the variation in growth for the period 1870 to 1890 .

During the period from 1890 to 1913, however, columns (5) and (6) show that the tariff variable is significant once again and indicate that open political institutions do not appear to have been critical during this period. An important reason for this change is that Russia, which had performed poorly before 1890, grew rapidly thereafter. Although Russia is listed as having one of the worst political regimes in 1890, apparently this did not prevent the emergence of growth. ${ }^{10}$

The importance of institutions, at least in the 1870 to 1890 period, is consistent with the findings of Morris and Adelman (1989, p. 1418), who stress that the "nineteenth century development experience underlies the crucial importance of institutions for successful economic growth. In our results, the speed of economic growth in the European periphery and landabundant overseas countries depended upon market systems, land tenure arrangements, and foreign-dominated institutions that provided capital, labor, and entrepreneurship." Argentina illustrates the importance of such institutions. Many land-abundant regions had the potential for growth in the late nineteenth century, but Argentina realized that potential. Rapid economic

10 "Russian modern economic growth began under unfavorable circumstances," Gregory (1994, p. 36) observes. "Long-term property rights had not been established in agriculture, onerous tariff barriers protected the domestic economy from competition; political instability had begun to grow, and the government bureaucracy was rife with corruption." 
growth was fueled by enormous inflows of foreign capital and labor, but these flows occurred because of the strength of Argentine political institutions. As Cortés Conde (1993, p. 76) notes, "The effective exercise of civil liberty and the legal security promoted by the constitution, and which was put into practice with the final organization of the state . . were important prerequisites for guaranteeing the free movements of labour and capital."

\section{Tariffs and Changes in Employment Structure}

The previous section examined the relationship between certain preconditions - such as initial income, initial tariffs, initial political structure - and subsequent growth. The findings were unsatisfying, because tariffs were sometimes related to growth and sometimes not, and incomplete, because the correlations tell us nothing about the possible mechanisms by which tariffs affected growth.

The most obvious mechanism is that tariffs altered domestic relative prices and thereby shifted resource allocation in such as way as to promote economic growth. Kuznets (1971) noted that modern economic growth is invariably associated with structural economic changes. In particular, he noted that output per worker in agriculture is significantly lower than in industry and services, although this diminished as per capita income rose. And he noted that a high rate of growth in output per worker was associated with a shift of resources (such as the sectoral allocation of employment) away from agriculture and toward industry and services. By altering relative prices, tariff policy could promote or retard this shift away from agriculture.

The "dualist" interpretation of the productivity gap between agriculture and other sectors is much debated (Timmer 1988; Schmitt 1989). The view that resources are more productive 
(higher value-added per worker) when employed outside of agriculture was one of the theoretical bases for import substitution policies as conceived in the 1950s. This was countered by the view that policies biased against the agricultural sector were a mistake and not only reduced rural incomes but may have inhibited growth in agricultural productivity that was an important element of the growth process. The shift of resources out of agriculture could lead to growth simply because it moves economic activity from non-market household production (where it is not measured) to the commercialized market sector (where it is measured).

Setting aside the difficulties of interpretation for the moment, such structural changes are relevant not just in the period studied by Kuznets but in the late nineteenth century as well. Broadberry (1998) showed how the shift in employment away from agriculture combined with sectoral productivity changes (particularly in services) enabled Germany and the United States to overtake the United Kingdom in per capita GDP during this period. Such shifts have been important even in the post World War II period: Temin (2002) shows how the cross-country pattern of growth in Western Europe from 1950 to 1973 is strongly related to the initial share of the labor force in agriculture. Countries with a high initial share of the labor force in agriculture had a greater opportunity to achieve high growth rates through the reallocation of resources between sectors than countries with few resources devoted to agriculture.

Yet the initial condition of the share of the labor force in agriculture in 1870 does not add to the explanatory power of the regressions in Tables 1 and 2. As Figure 4 shows, countries with a low share of employment in agriculture tended to grow slowly: the United Kingdom, Australia, the Netherlands, and Belgium are unique in having a low share in 1870. These economically mature countries had already made the transition to a more diversified economy and therefore 
had less scope for achieving growth by shifting resources out of agriculture. This fact may explain why Australia's growth experience was so lackluster in comparison to that of Argentina, Canada, and the United States, despite other similarities (such as high tariffs, abundant land, and scarce labor). ${ }^{11}$ But beyond these countries, there is no monotonic relationship between the initial share and subsequent growth: some countries that started with a large fraction of the labor force in agriculture (such as Canada and Argentina) grew rapidly, while others grew more slowly (such as Finland and Spain).

The countries registering the most rapid growth between 1870 and 1913, however, were the countries in which the share of employment in agriculture fell the most. Figure 5 presents the unconditional correlation and Table 3 confirms it: in columns (1) - (4), growth is strongly related to the (absolute) change in the share of employment devoted to agriculture, even after controlling for initial per capita GDP and the initial share of the labor force in agriculture. These two variables are closely associated, but direction of causality is unclear: the reallocation of employment across sectors could have raised growth rates, but growth itself could have produced the shift in the allocation of labor.

A declining employment share of agriculture was not quite equivalent to the movement of labor into industry. Figure 6 illustrates the relationship between changes in the employment share in industry between 1870 and 1913 and economic growth. Countries such as Sweden and New Zealand saw large increases in the share of the labor force devoted to industry, but

11 As Butlin (1964, p. 195) notes, "The proportion of people engaged in agricultural and pastoral activities rose a little in the 'sixties, from 29 to 31 percent, remained at this level in the 'seventies and between 1881 and 1981, fell to 26 percent. It is important to note this timing: the trend toward a high urban society was well advanced before there was a relative stagnation of the main rural industries." 
experienced just modest growth. As columns (5) and (8) indicate, growth is tied to an increase in the share of the labor force devoted to industry, defined as manufacturing and construction, and services only after controlling for the initial share in those industries. For the core countries, the magnitude of the coefficient on services exceeds that on industry. Thus, rapidly growing countries were those that saw labor shift from agriculture into commercialized sectors (industry and services), but industry was not necessarily the most important aspect of this shift.

This distinction - that shifting employment out of agriculture was not equivalent to shifting it into industry - is illustrated by the examples of Germany and the United States. In these two cases, Broadberry (1998) notes, most of the labor released from agriculture was not absorbed in manufacturing. ${ }^{12}$ The sectors enjoying the largest increase in the labor share were distribution, finance, and other services. These sectors is also experienced the largest relative productivity growth, particularly in construction, utilities, transportation and communication, and distribution. As Broadberry (1998, p. 376) concludes, "both Germany and the United States overtook Britain in terms of aggregate labor productivity largely by shifting resources out of agriculture and by improving comparative labor productivity in services rather than by improving comparative labor productivity in manufacturing."

If shifting labor out of agriculture was proximately related to growth, then trade policy could have accelerated or impeded that movement. Agricultural exporting countries that

12 In Germany between 1870 and 1910, the share of the labor force in agriculture fell 15.3 percentage points (from 49.5 percent to 34.2 percent), but the share in manufacturing increased only 4.8 percentage points (from 24.7 percent to 29.5 percent). In the United States over the same period, the share of the labor force in agriculture dropped 18 percentage points (from 50.0 percent to 32.0 percent), but the share in manufacturing rose only 4.9 percentage points (from 17.3 percent to 22.1 percent). 
imposed tariffs on imported manufactured goods would have accelerated the structural shift, while agricultural importing countries with tariffs on imported foodstuffs would have slowed the shift. ${ }^{13}$ Therefore Germany may have inhibited the movement out of agriculture by imposing tariffs on agricultural imports, whereas the United States may have accelerated it by imposing tariffs on manufactured imports. ${ }^{14}$ France, Germany, Spain, and Sweden were notable for imposing fairly substantial import duties on agricultural goods in the aftermath of the Great Grain invasion of the 1880s (O'Rourke 1997, Bairoch 1989). As a result, they may have slowed the movement of labor out of agriculture. Denmark and the United Kingdom stand out as being relatively open, but Denmark's per capita income grew quite rapidly even though it was an agricultural exporting country that underwent little structural change in employment. In Italy, tariffs may not have been a significant factor one way or the other in affecting labor's movement out of agriculture. ${ }^{15}$

13 This channel is the opposite of the one proffered by Bairoch (1972, p. 243), who implies that free trade was bad for Europe because it harmed agriculture: "The negative character of the period free trade for continental Europe was not cause by an influx of manufactured goods from more productive industries across the Channel, but by the influx of cereals, especially from overseas. ... [which] cause[d] deceleration of growth in agriculture and, hence of the economy as a whole, since farming still represented a very important sector of the economy."

14 As Broadberry (1998, p. 391) notes, "In contrast to the United States, where agriculture was an exportable, in Germany agriculture was an importable sector but was prevented from shrinking too rapidly by a policy of protection. Hence the release of labor from agriculture was retarded in Germany by policies to switch demand away from imports towards domestically supplied produce."

15 In the case of Italy, Federico and Tena (1999, pp. 121, 125) concluded that "(1) trade policy was not very consistent over time; (2) protection for manufactures was low and sometimes inferior to that on agricultural products; and (3) the policy toward industrial goods was not inspired by any consistent principle (such as a preference for consumer goods, or finished products or labor intensive goods). . . industry as a whole was not given an artificial advantage 
Table 4 explores whether tariffs influenced the change in the share of employment in agriculture. Column (1) indicates that tariffs alone are not strongly related to the change in share, but this does not control for a country's comparative advantage. Column (2) considers the differential impact of tariffs in agricultural exporting and importing countries by interacting the tariff with a dummy variable indicating whether the country was an agricultural exporting country in the 1880 s. Every country is considered an agricultural exporting countries except those which were consistent net exporters of manufactured goods throughout this period: Austria-Hungary, Belgium, France, Germany, the Netherlands, Switzerland, and the United Kingdom (Lovejoy 1945, pp. 160-161). Agricultural exporting countries saw smaller movements of labor out of agriculture in comparison to agricultural importing countries (as indicated by coefficient of -0.20), but the interaction of tariffs and the agricultural exporting indicator is positive and significant (with a coefficient of 0.09). This regression evidence suggests that agricultural exporting countries with high tariffs were indeed able to shift employment into industry and services.

The magnitudes of this effect can be calculated from the column (2) regression. An agricultural exporting country with the average tariff of an agricultural exporting country would essentially experience structural change no different from that of agricultural importing countries. The average tariff multiplied by the interaction term of 0.08 is slightly larger than - and hence cancels out - the -0.20 coefficient on agricultural exporters. A one standard deviation increase (from the mean) in the tariff of an average agricultural exporting country would reduce the share of employment in agriculture by about 5 percentage points. According to column (4) of Table 3, 
every percentage point reduction in the share of the labor force in agriculture is associated with an increase in growth of 0.0301 percentage points. Therefore, a 5 percentage point reduction would boost growth by 0.15 percentage points, or by 13 percent for the average agricultural exporter between 1870 to 1913 . By this evidence, tariffs in agricultural exporting countries may have accelerated structural change and thereby provided a modest boost to economic growth.

The strength of this conclusion is weakened considerably by two important qualifications. First, Argentina appears to be an influential outlier, as it appears in Figure 5. When Argentina is excluded from the column 2 regression, as in column 3, the agricultural exporter and tariff coefficients no longer significant and the magnitudes are substantially reduced. While the signs remain unchanged, indicating that the above relationship still holds as a general tendency, the relationship is quite weak to judge by the decline in the $\mathrm{R}^{2}$. The interpretation is further complicated by evidence from Argentina, considered in the next section, indicating that changes in employment structure may have been driven by export-led growth in staples rather than by high tariffs leading to import substitution.

Second, the inclusion of polity (in column 4) reduces the significance of the interaction terms, although the size of the coefficient is only slightly reduced. (This column includes Argentina; the sample size falls by one due to the lack of a policy indicator for Finland.) More competitive political systems experienced greater shifts in the structure of employment, perhaps because practices tying employment to agriculture (serfdom, land-tenure arrangements, etc.) were weaker in such systems. Thus, while the column 2 regression held out the promise of pinning down the tariff-growth relationship during this period, that link does not appear to be robust.

Repeating the approach in table 4, table 5 explores whether trade policy affected the 
movement of labor into industry. In all columns of the table, the change in the labor force devoted to industry is slower in countries with higher initial shares of the labor force in industry. The column 2 regression indicates that countries with higher tariffs experienced a somewhat greater movement of labor into industry. However, the effect is not large: a one standard deviation increase in share of the labor force in industry by just 1.9 percentage points. There does not appear to be a differential effect based on the comparative advantage of the country: although agricultural exporters are slightly less likely to shift labor into industry (not a statistically significant result), agricultural exporters do not appear to be different from agricultural importers in the effect of the tariff. Unlike table 4, these findings are robust to the exclusion of Argentina (column 3) and to the inclusion of the initial polity control (column 4).

The notion that agricultural exporting countries could increase growth by using tariffs to shift labor out of agriculture and into industry is straightforward, but the empirical evidence supporting that notion is not strong. Another qualification is that causality between growth and structural change remains indeterminate: growth could have led to changes in the structure of employment rather than having been the result of structural changes. Can country evidence on trade policy and structural change add any insight to these linkages?

\section{Country Evidence on Sectoral Employment Changes}

In the evidence considered above, Argentina (as well as Canada) stands out as a high tariff, high growth outlier. What can the case of Argentina tell us about the relationship between trade policy and economic growth during this period?

Although Argentina achieved the world's highest recorded rate of growth in per capita 
income during this period and had very high average tariffs, its growth was not based on industrialization due to import substitution and its trade policy was not part of an inward-oriented development policy. Instead, Argentina experienced a foreign investment boom in the $1880 \mathrm{~s}$, particularly in railroad construction, that paved the way for an enormous expansion in exports of staple products after 1890. As Cortés Conde (1993, p.75) explains, the "growth which changed Argentina was based on the exploitation of staples: agricultural and cattle products which found an outlet in international markets."

The expansion of agricultural production for export fueled the rise of complementary activities, both in manufacturing (food processing) and in services (transportation and construction). These subsidiary industries were geared toward developing and servicing the agricultural exports and absorbed an increasing share of the labor force. According to Reynolds (1985, p. 88), “manufacturing output [in Argentina] during this period grew only a little faster than GDP and was linked rather closely with export expansion. Meat-packing plants, flour mills, and wool-washing establishments shipped a large part of their output abroad. Railroad construction and repair, other export-oriented infrastructure facilities, and housing and urban facilities for immigrants also provided a stimulus to manufacturing. ... manufacturing growth came mainly from export expansion plus growth of the domestic market, with import substitution playing a minor role."

Thus, "industrial growth did not stem from protectionist tariffs," as Cortés Conde (1993, p. 68) notes. Solberg (1987, p. 106) adds that "Although some Argentine industries did enjoy marked tariff protection, no government during the 1880-1930 period attempted a consistent protectionist policy to spur industrial growth through massive import substitution." 
Argentina's tariff code was not designed to promote industrialization based on import substitution. Most capital goods and intermediate products that were related to production and exports of staples entered duty free. "Argentina, with her great railway system, her docks, her public utilities, her developing industries naturally taxed imports like machinery, iron, steel, chemicals and cotton yarn very lightly," as Platt (1972, p. 84) points out. To raise revenue for the government, high tariffs were imposed on imported luxuries (including manufactured goods for consumers), sugar and wine (with some protective effect), and tobacco. Díaz Alejandro (1970, p. 280) quotes a U.S. Tariff Commission report stating that prior to World War I "the Argentine customs tariff was primarily a fiscal instrument, and rates of duty were adjusted to obtain the revenue desired."

Thus, though Argentina was a high tariff, high growth outlier during this period, its trade policy does not appear to have been designed to promote industrialization through import substitution. And the structural change in employment seems to have been the result of rapid growth in the export of staples rather than having been the underlying cause.

Canada was another high tariff country that experienced incredibly rapid growth from 1896 to 1913 . Like Argentina, this growth was based on large investments in railroads (particularly the Canadian Pacific Railroad which extended into the prairies) in the 1880 s that made possible an export boom in its staple product, wheat. As Urquhart (1986, pp. 35-36) notes, the major expansion from 1900 to 1913 was "a classic investment boom, a major part of it related directly or indirectly to the settlement of the west. . . that the settlement of the west was based on the expectation, in the minds of the settlers, of there being a viable [international] market for wheat is beyond doubt." In fact, while the share of Canada's labor force in industry 
rose sharply between 1870 and 1890 when growth was modest, the share moved from just 26.3 percent in 1891 to 26.9 percent in 1911 when growth was rapid (Urquhart 1993, pp. 24, 305).

Although Canada's tariff policy was more overtly protectionist than Argentina's, the country did not attempt widespread import substitution. Though "avowedly protectionist in intent, the tariff was calculated to assure those Canadian industries deemed capable of expansion the necessary raw materials and partially manufactured goods from abroad at prices unenhanced by duties. Thus 'holes' were left in the tariff through which such goods might pass, especially after 1907. These essential materials for Canadian industry plus substantial amounts of capital equipment for railway construction made up the bulk of imports," write McDiarmid (1946, p. 240). Even though both Argentina and Canada had very high tariffs, as measured by customs revenue divided by imports, high tariff revenue measures do not necessarily reflect protectionist policies. Both Argentina and Canada in 1913 were among the world's most open economies in terms of trade in goods, according to Estevadeordal's (1997) distance and factor-endowments based calculations. This suggests that the tariff measures are an imperfect indicator of a country's trade-orientation. ${ }^{16}$

In many countries, import duties were primarily designed to raise fiscal revenue for the

16 And tariffs designed to promote manufacturing may fail to do so. In Australia, the colony of Victoria imposed high tariffs as a means of promoting import substitution, but the policy was poorly designed. As Boot (1998, pp. 96-97) observed, "the Victorian system [of tariffs] was largely arbitrary, often irrational, and frequently harmful to manufacturing interests: luck rather than design often determined whether a particular industry benefitted. The net effect on industrial development is thus difficult to unscramble. .. . Tariffs on machinery delayed the introduction of new techniques and were enough to suppress meat canning as an industry in Victoria. The carriage-making industry was also hit by tariffs on parts, while the footwear industry languished because of the tariff on leather. Taking these points together, it seems that the tariff had a marginal and somewhat arbitrary effect on Victorian manufacturing development." 
government. The structure of revenue tariffs can be quite different from the structure of protective tariffs. Revenue tariffs are often levied (heavily) on just a few key commodities (often alcoholic beverages, tobacco products, coffee and tea, and the like), but can often collect as much revenue as broadly based tariffs designed to protect domestic producers. Tena (2001) examines the importance of such fiscal tariffs during this period.

The countries with the highest tariffs - Argentina, Australia, Canada, New Zealand, Russia, and the United States - share a common feature: abundant land and scarce labor. As Irwin (2001) points out, public finance and political economy reasons dictate that such countries would be prone to using customs duties to raise government revenue. The relative factor endowments of these countries, giving them the ability to attract foreign capital investment and foreign labor through immigration (except for the latter in Russia), may have given these countries good growth prospects for reasons unrelated to the tariff.

Indeed, if the high land to labor ratios gave these countries unusually good growth prospects (a large share of labor in agriculture capable of shifting into other sectors) and also induced them to use tariffs for revenue raising purposes, the tariff-growth correlation could reflect two unrelated phenomena.

\section{Conclusions}

The principal findings of this paper can be summarized as follows:

1. The positive correlation between tariffs and growth, conditional only on the initial level of income, is most pronounced for the period between 1890 and 1913. Between 1870 and 1890, democratic political institutions appear to be positively related to growth. 
2. The most rapidly growing countries in the late nineteenth century were those that saw a decline in the share of employment in agriculture.

3. The effect of tariffs on the shift of labor out of agriculture depended upon a country's comparative advantage: some countries slowed the movement of labor out of agriculture by imposing high duties on imported agricultural goods, whereas others may have accelerated the shift through duties on manufactures. However, the evidence that agricultural exporting countries were able to use tariffs to increase growth is weak.

4. Rapid growth in Argentina and Canada - two high tariff, high growth outliers - was based on an export-orientation in their staple products, not industrialization based on import substitution.

These findings suggest that tariffs were not a critical factor behind the late nineteenth century growth experience. This conclusion is consistent with Morris and Adelman (1989, p. 1420), who observe that "success along this inward-oriented growth path varied greatly [in the late nineteenth century] . . . . in moderately backward, import-substituting countries protection levels varied greatly and did not systematically accelerate economic growth . . . In sum, the effects of tariff policies are complex and vary greatly across countries in ways depending strongly on resources, institutions, and government strategies." 


\section{References}

Bairoch, Paul, et al. The Working Population and Its Structure. Brussels: Université Libre de Bruxelles, 1968.

Bairoch, Paul. "Free Trade and European Economic Performance in the $19^{\text {th }}$ Century." European Economic Review 3 (November 1972): 211-245.

Bairoch, Paul. "European Trade Policy, 1815-1914." In Peter Mathias and Sidney Pollard (eds.), Cambridge Economic History of Europe, Vol. XIII. New York: Cambridge University Press, 1989.

Baumol, William J. "Productivity Growth, Convergence, and Welfare: What the Long-run Data Show." American Economic Review 76 (December 1986): 1072-85.

Broadberry, Stephen N. "How Did the United States and Germany Overtake Britain? A Sectoral Analysis of Comparative Productivity Levels, 1870-1990." Journal of Economic History 58 (June 1998): 375-407.

Boot, H. M. "Government and the Colonial Economies." Australian Economic History Review 38 (March 1998): 74-101.

Butlin, N. G. Investment in Australian Economic Development, 1861-1900. Cambridge: Cambridge University Press, 1964.

Cortés Conde, Roberto. "The Growth of the Argentine Republic, c. 1870 - 1914." In Leslie Bethell (ed.), Argentina Since Independence. New York: Cambridge University Press, 1993.

Clemens, Michael A., and Jeffrey G. Williamson. “A Tariff-Growth Paradox? Protection's Impact the World Around, 1875-1997.” NBER Working Paper No. 8459, September 2001.

De Long, J. Bradford. "Productivity Growth, Convergence, and Welfare: Comment." American Economic Review 78 (December 1988): 1138-1154.

Estevadeordal, Antoni. "Measuring Protection in the Early Twentieth Century." European Review of Economic History 1 (April 1997): 89-126.

Federico, Giovanni, and Antonio Tena. "Did Trade Policy Foster Italian Industrialization? Evidence from Effective Protection Rates, 1870-1913.” In Alexander J. Field (ed.), Research in Economic History, Vol. 19. Greenwich, CT: JAI Press, 1999.

Gregory, Paul R. Before Command: An Economic History of Russia from Emancipation to the First Five-Year Plan. Princeton: Princeton University Press, 1994. 
Irwin, Douglas A. "Free Trade and Protection in Nineteenth Century Britain and France Revisited: Comment on Nye," Journal of Economic History 53 (March 1993): 146-152.

Irwin, Douglas A. "Interpreting the Tariff-Growth Correlation in the Late Nineteenth Century." American Economic Review (Papers \& Proceedings) 92 (May 2002), forthcoming.

Knack, Stephen, and Philip Keefer. "Institutions and Economic Performance: Cross-Country Tests Using Alternative Institutional Measures." Economics and Politics 7 (November 1995): 207-27.

Krueger, Anne O. "Trade Policy and Economic Development: How We Learn.” American Economic Review 87 (March 1997): 1-22.

Kuznets, Simon. Economic Growth of Nations: Total Output and Production Structure. Cambridge: Harvard University Press, 1971.

Lovejoy, A. Industrialization and Foreign Trade. Geneva: League of Nations, 1945.

Maddison, Angus. The World Economy in the Twentieth Century Paris: OECD, 1989.

Maddison, Angus. Dynamic Forces in Capitalist Development. New York: Oxford University Press, 1991.

Maddison, Angus. Monitoring the World Economy, 1820-1992 Paris: OECD, 1995.

Marshall, Monty G., and Keith Jaggers. Polity IV Project: Political Regime Characteristics and Transitions, 1800-1999. Dataset Users Manual. Center for International Development and Conflict Management, University of Maryland, College Park, MD, December 1, 2000. Available at http://www.bsos.umd.edu/cidcm/inscr/polity.

McDiarmid, Orville J. Commercial Policy in the Canadian Economy. Cambridge: Harvard University Press, 1946.

Morris, Cynthia Taft, and Irma Adelman. "Nineteenth Century Development Experience and Lessons for Today." World Development 17 (September 1989): 1417-1432.

O’Rourke, Kevin H. “The European Grain Invasion, 1870-1913.” Journal of Economic History 57 (December 1997): 775-801.

O'Rourke, Kevin H. "Tariffs and Growth in the Late $19^{\text {th }}$ Century." Economic Journal 110 (April 2000): 456-483.

O’Rourke, Kevin H., and Jeffrey G. Williamson. Globalization and History: The Evolution of 
the Nineteenth Century Atlantic Economy. Cambridge, MIT Press, 1999.

Platt, D. C. M. Latin America and British Trade 1806-1914. London: Adam \& Charles Black, 1972.

Prados de la Escosura, Leandro. "International Comparisons of Real Product, 1820-1990: An Alternative Data Set.” Explorations in Economic History 37 (January 2000): 1-41.

Pritchett, Lant. "Measuring Outward Orientation in LDCs: Can It Be Done?" Journal of Development Economics 49 (May 1996): 307-35.

Pritchett, Lant. "Divergence, Big Time." Journal of Economic Perspectives 11 (Summer 1997): 3-17.

Reynolds, Lloyd. Economic Growth in the Third World, 1850-1980. New Haven: Yale University Press, 1985.

Rodríguez, Francisco, and Dani Rodrik. "Trade Policy and Economic Growth: A Skeptic's Guide to the Cross-National Evidence." In Ben S. Bernanke and Kenneth Rogoff (eds.), NBER Macroeconomics Annual 2000. Cambridge: MIT Press, 2001.

Schmitt, Gunther. "Simon Kuznets' 'Sectoral Shares in Labor Force': A Different Explanation of His (I+S)/A Ratio.” American Economic Review 79 (December 1989): 1262-1276.

Solberg, Carl E. The Prairie and the Pampas: Agrarian Policy in Canada and Argentina, 18801930. Stanford: Stanford University Press, 1987.

Taylor, Alan M. "Sources of Convergence in the Late Nineteenth Century." European Economic Review 45 (September 1999): 1621-1645.

Temin, Peter. "The Golden Age of European Growth Reconsidered." European Review of Economic History, forthcoming 2002.

Tena, Antonio. "Measuring Protection over Time: Revenue and Protective Products in $19^{\text {th }}$ Century Commercial Policy History.” Department de Historia Economica e Instituciones, Universidad Carlos III de Madrid, October 2001.

Timmer, C. Peter. "The Agricultural Transformation." In Hollis Chenery and T. N. Srinivasan (eds.), Handbook of Development Economics. Vol. 1. Amsterdam: Elsevier, 1988.

Urquhart, M. C. "New Estimates of Gross National Product, Canada, 1870-1926: Some Implications for Canadian Development." In Stanley L. Engerman and Robert E. Gallman (eds.) Long-Term Factors in American Economic Growth. Chicago: University of Chicago Press, 
1986.

Urquhart, M. C. Gross National Product, Canada, 1870-1926: The Derivation of the Estimates. Montreal: McGill-Queen's University Press, 1993. 
言竞

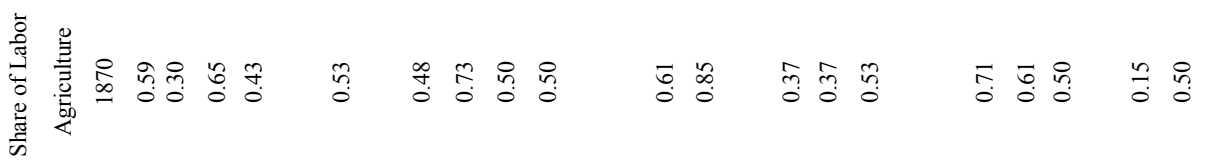

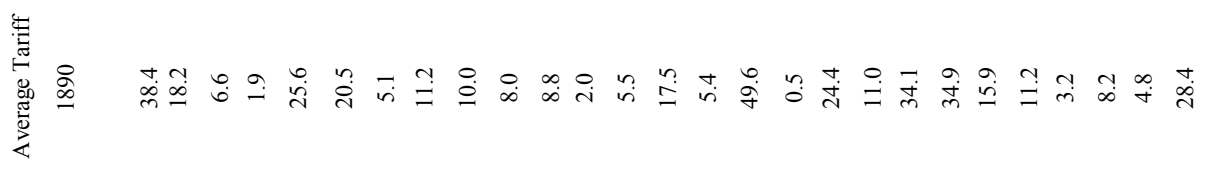

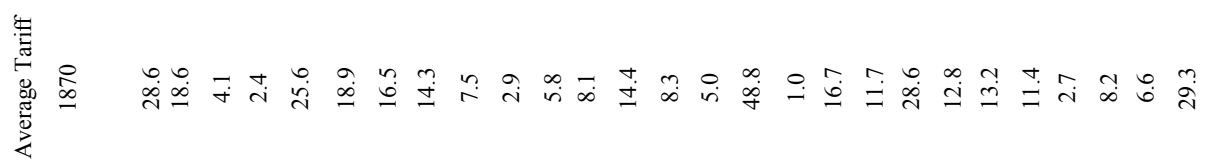
$\stackrel{i}{i}$
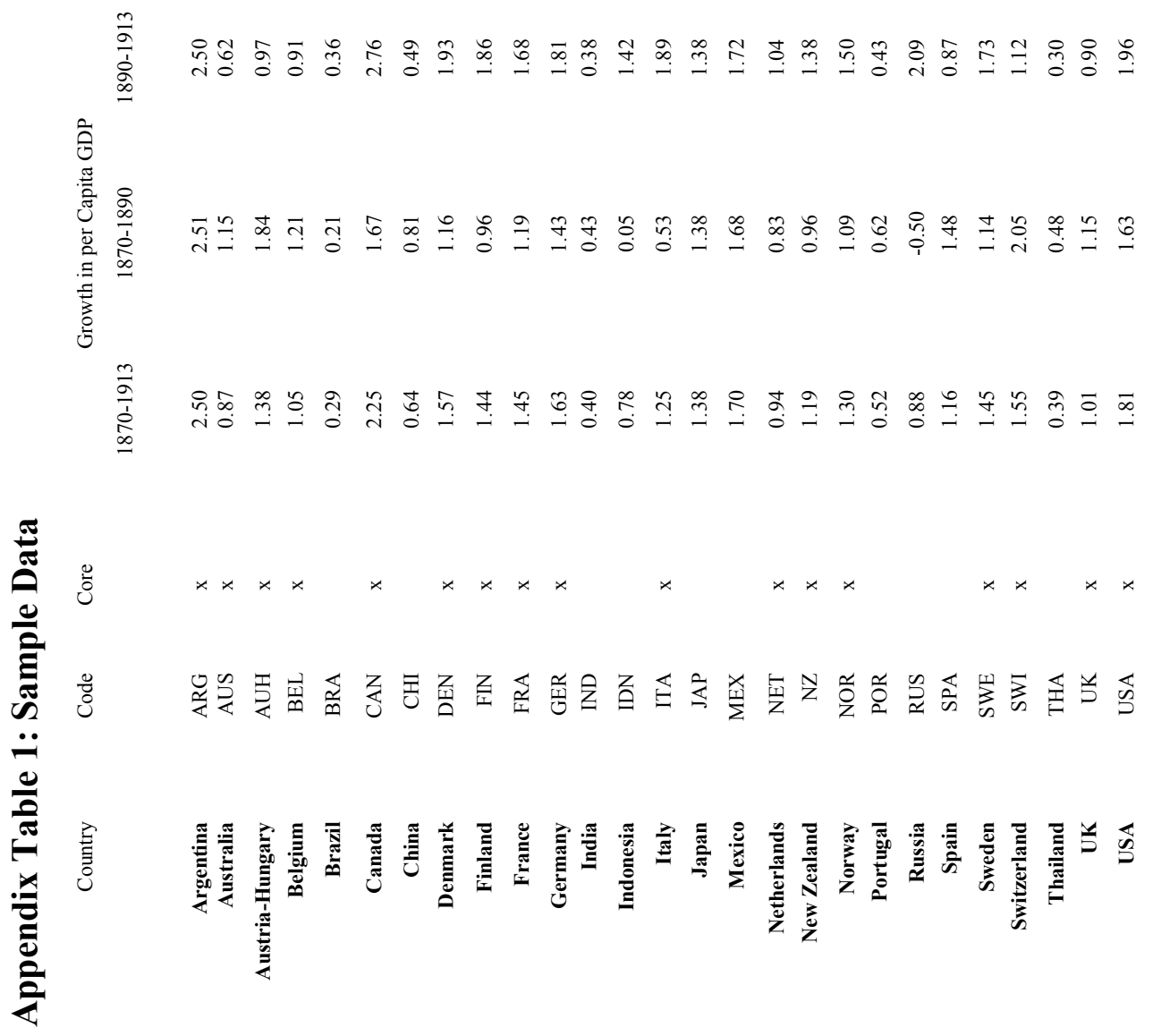

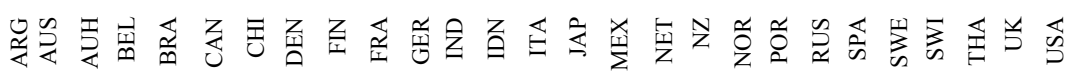
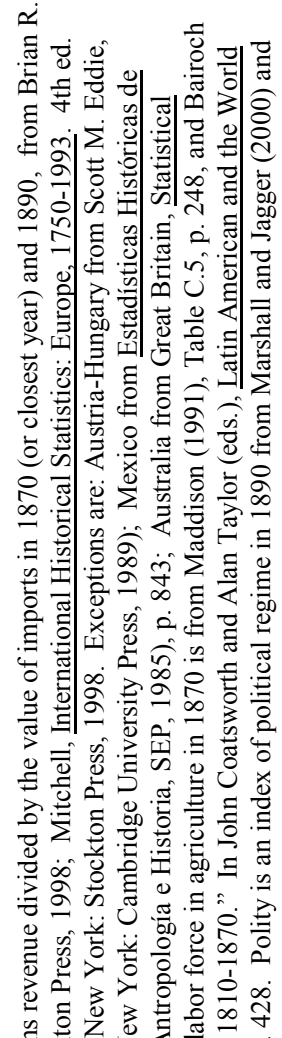

矛哇 ची

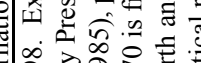
o 20

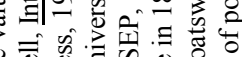

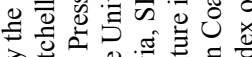
西卷

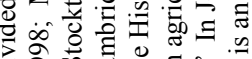

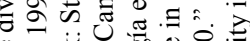

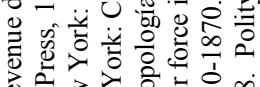

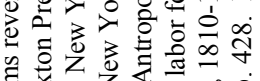

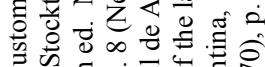
के क्ञ

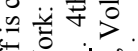
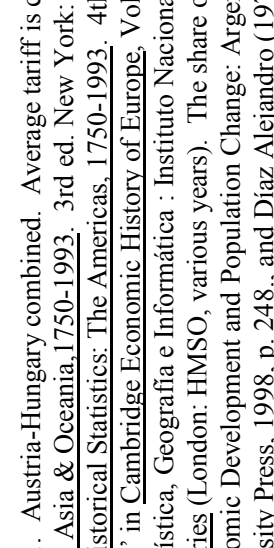

乙 


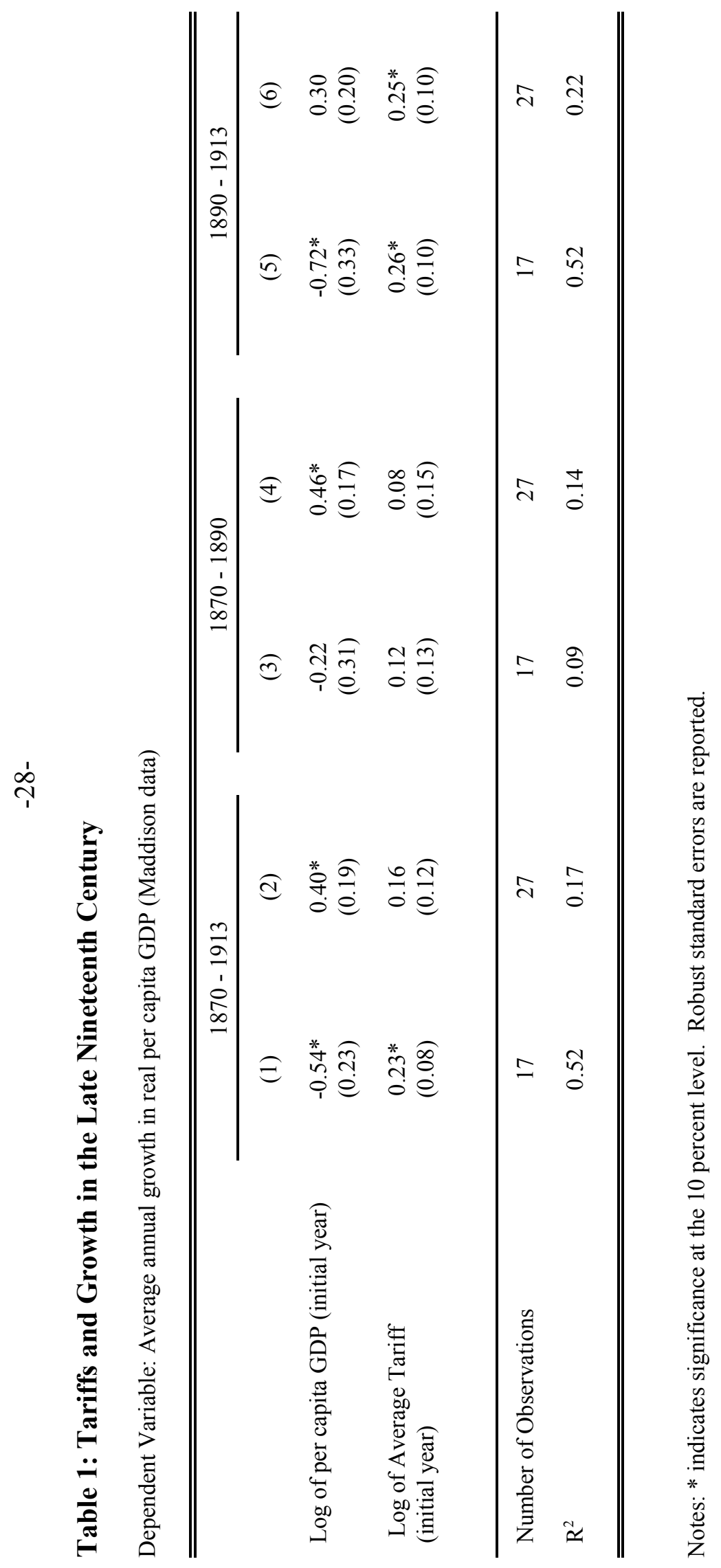




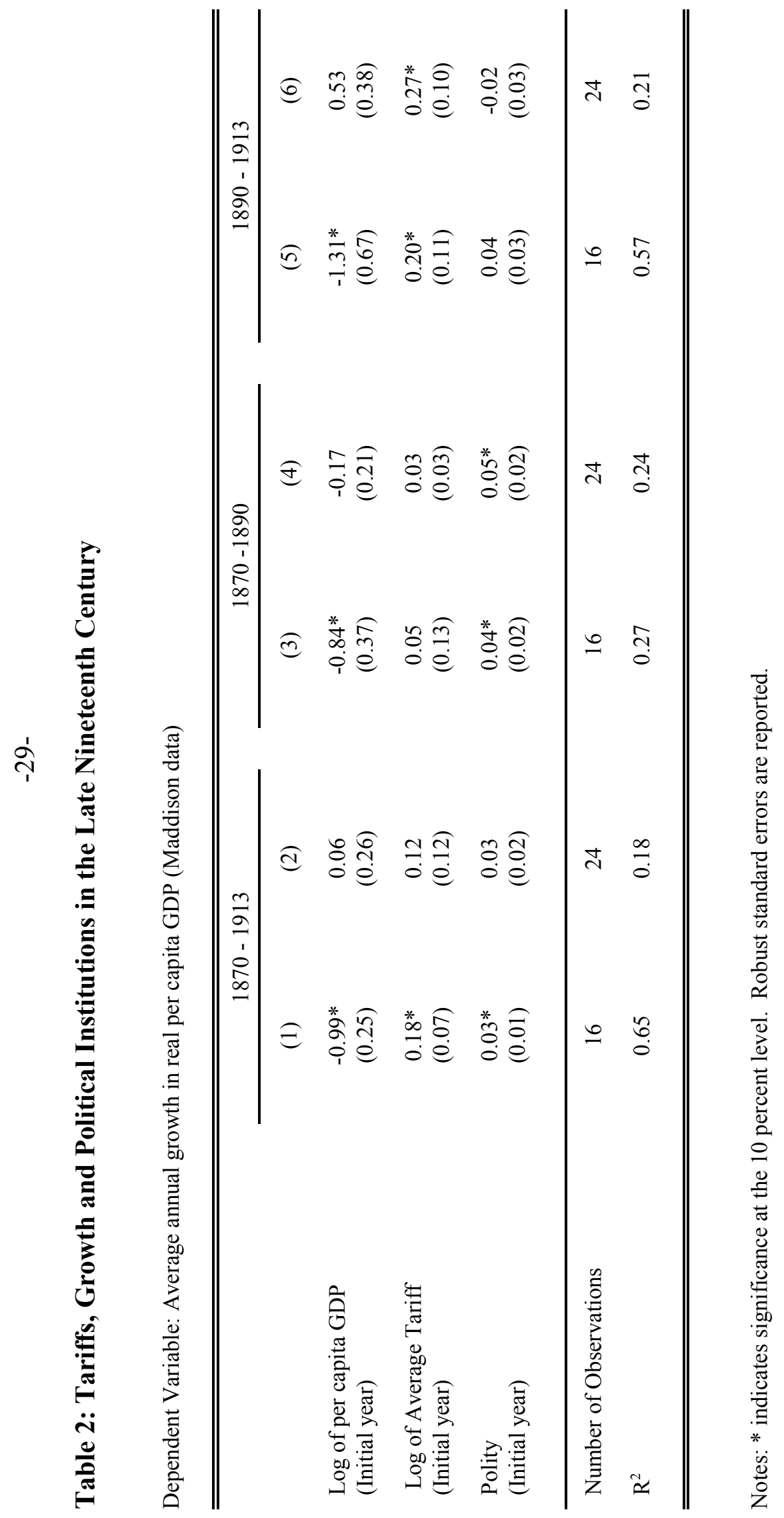




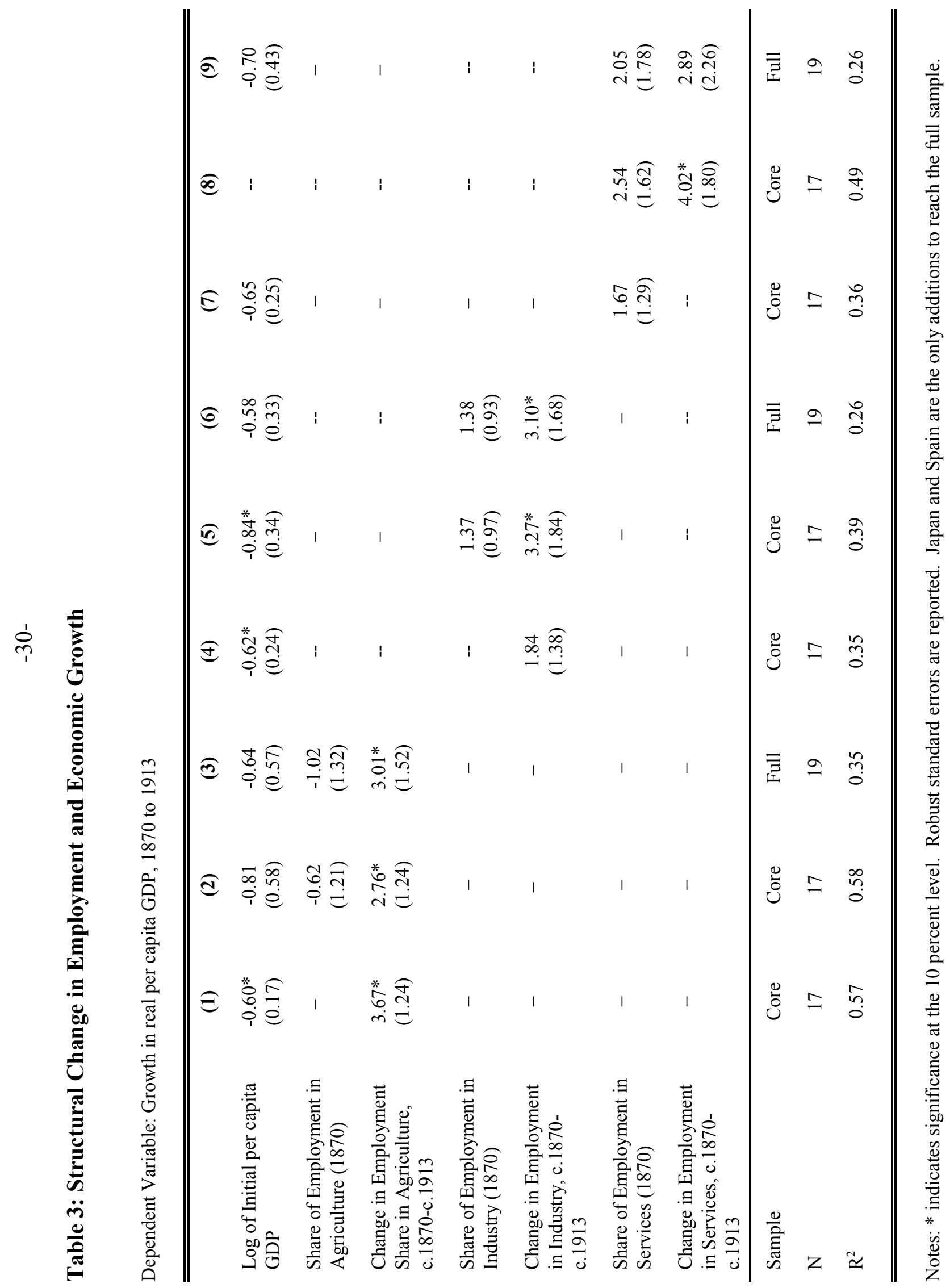


Table 4: Determinants of Labor's Movement Out of Agriculture, 1870-1913

Dependent Variable: Change in the Share of Employment in Agriculture, 1870-1913

\begin{tabular}{|c|c|c|c|c|}
\hline & (1) & (2) & (3) & (4) \\
\hline $\begin{array}{l}\text { Share of Labor Force in } \\
\text { Agriculture, } 1870\end{array}$ & $\begin{array}{c}0.11 \\
(0.08)\end{array}$ & $\begin{array}{l}0.16^{*} \\
(0.10)\end{array}$ & $\begin{array}{c}0.14 \\
(0.09)\end{array}$ & $\begin{array}{l}0.27^{*} \\
(0.08)\end{array}$ \\
\hline Log of Tariff in 1870 & $\begin{array}{c}0.003 \\
(0.017)\end{array}$ & $\begin{array}{l}-0.01 \\
(0.03)\end{array}$ & $\begin{array}{l}-0.01 \\
(0.03)\end{array}$ & $\begin{array}{l}-0.02 \\
(0.02)\end{array}$ \\
\hline $\begin{array}{l}\text { Log of Tariff in } 1870 * \\
\text { Agricultural Exporter }\end{array}$ & -- & $\begin{array}{l}0.08 * \\
(0.04)\end{array}$ & $\begin{array}{c}0.04 \\
(0.05)\end{array}$ & $\begin{array}{c}0.07 \\
(0.04)\end{array}$ \\
\hline Agricultural Exporter & -- & $\begin{array}{l}-0.20 * \\
(0.11)\end{array}$ & $\begin{array}{l}-0.12 \\
(0.12)\end{array}$ & $\begin{array}{l}-0.17^{*} \\
(0.10)\end{array}$ \\
\hline Polity in 1870 & - & -- & -- & $\begin{array}{l}0.004 * \\
(0.002)\end{array}$ \\
\hline $\mathrm{N}$ & 19 & 19 & 18 & 18 \\
\hline $\mathrm{R}^{2}$ & 0.08 & 0.25 & 0.15 & 0.47 \\
\hline
\end{tabular}

Notes: * indicates significance at the 10 percent level. Robust standard errors are reported. 
Table 5: Determinants of Labor's Movement Into Industry, 1870-1913

Dependent Variable: Change in the Share of Employment in Industry, 1870-1913

\begin{tabular}{|c|c|c|c|c|}
\hline & (1) & (2) & (3) & (4) \\
\hline $\begin{array}{l}\text { Share of Labor Force in Industry, } \\
1870\end{array}$ & $\begin{array}{l}-0.26^{*} \\
(0.11)\end{array}$ & $\begin{array}{l}-0.37^{*} \\
(0.15)\end{array}$ & $\begin{array}{l}-0.37^{*} \\
(0.15)\end{array}$ & $\begin{array}{l}-0.47 * \\
(0.15)\end{array}$ \\
\hline Log of Tariff in 1870 & $\begin{array}{c}0.009 \\
(0.008)\end{array}$ & $\begin{array}{l}0.022 * \\
(0.012)\end{array}$ & $\begin{array}{l}0.022 * \\
(0.012)\end{array}$ & $\begin{array}{l}0.025^{*} \\
(0.014)\end{array}$ \\
\hline $\begin{array}{l}\text { Log of Tariff in } 1870 * \\
\text { Agricultural Exporter }\end{array}$ & -- & $\begin{array}{c}0.013 \\
(0.027)\end{array}$ & $\begin{array}{c}0.016 \\
(0.035)\end{array}$ & $\begin{array}{l}-0.013 \\
(0.018)\end{array}$ \\
\hline Agricultural Exporter & -- & $\begin{array}{l}-0.083 \\
(0.070)\end{array}$ & $\begin{array}{l}-0.09 \\
(0.09)\end{array}$ & $\begin{array}{l}-0.025 \\
(0.049\end{array}$ \\
\hline Polity in 1870 & - & -- & -- & $\begin{array}{c}0.003 \\
(0.002)\end{array}$ \\
\hline $\mathrm{N}$ & 19 & 19 & 18 & 18 \\
\hline $\mathrm{R}^{2}$ & 0.34 & 0.40 & 0.40 & 0.55 \\
\hline
\end{tabular}

Notes: * indicates significance at the 10 percent level. Robust standard errors are reported. 
Figure 1: Average Tariff Rates, Selected Countries, 1870-1913

A. Low Tariff Countries

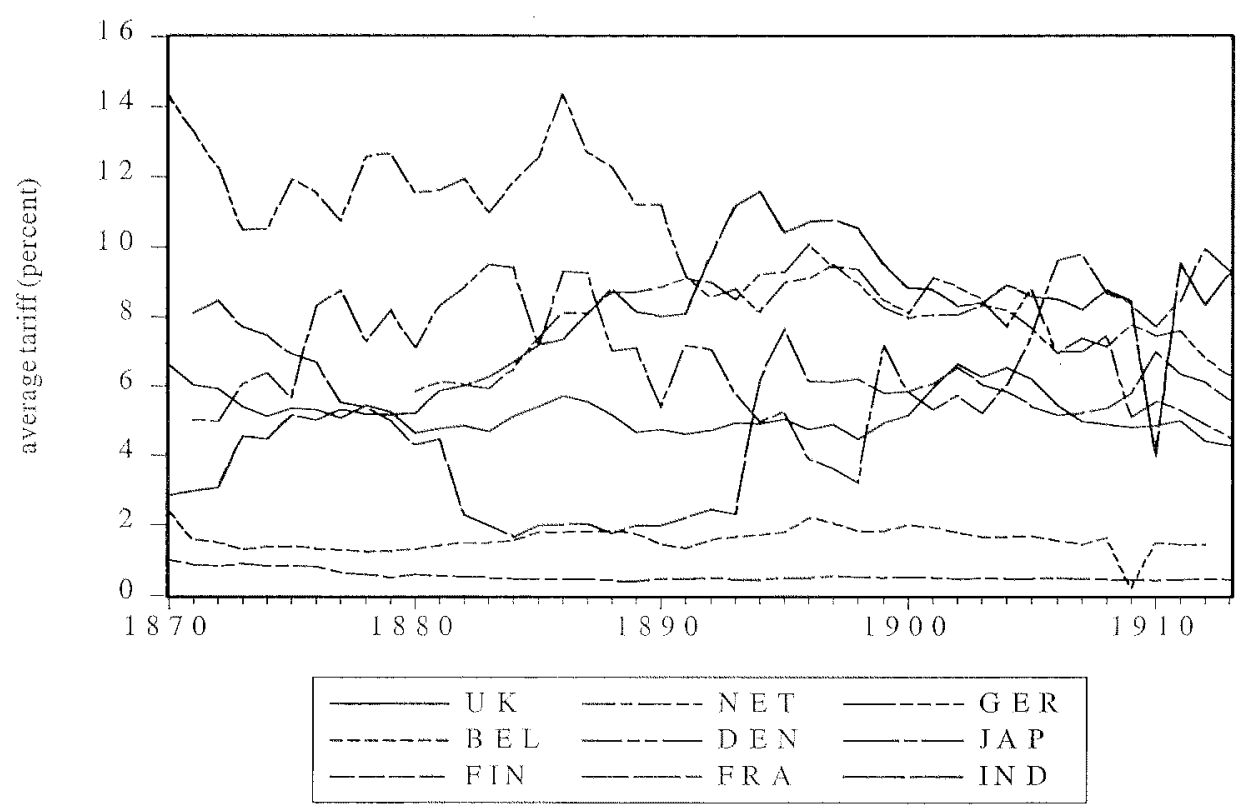

B. High Tariff Countries

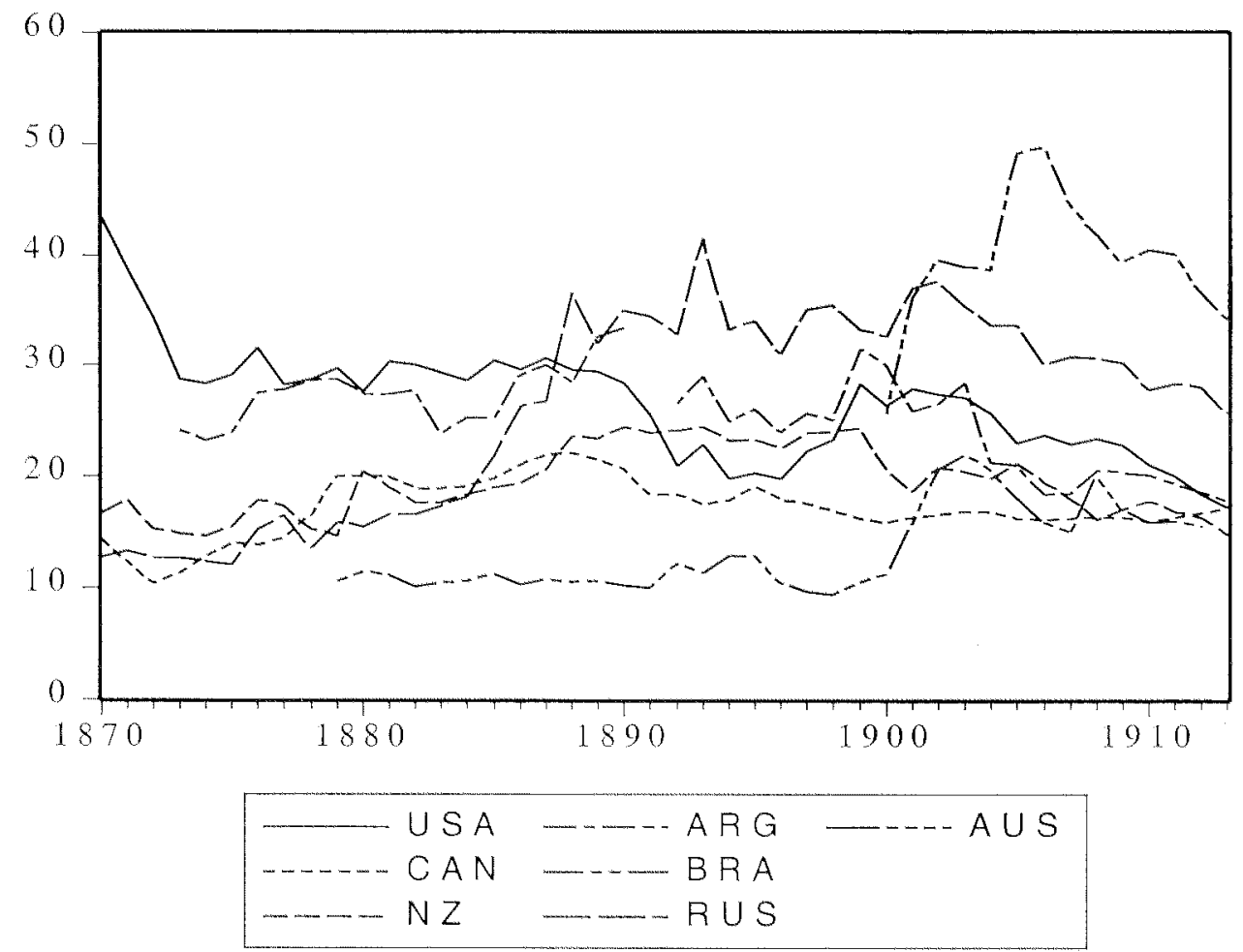


Figure 2: Average Tariffs and Average Annual Growth in per capita GDP, 1870-1913

A. Core Sample: 17 Countries

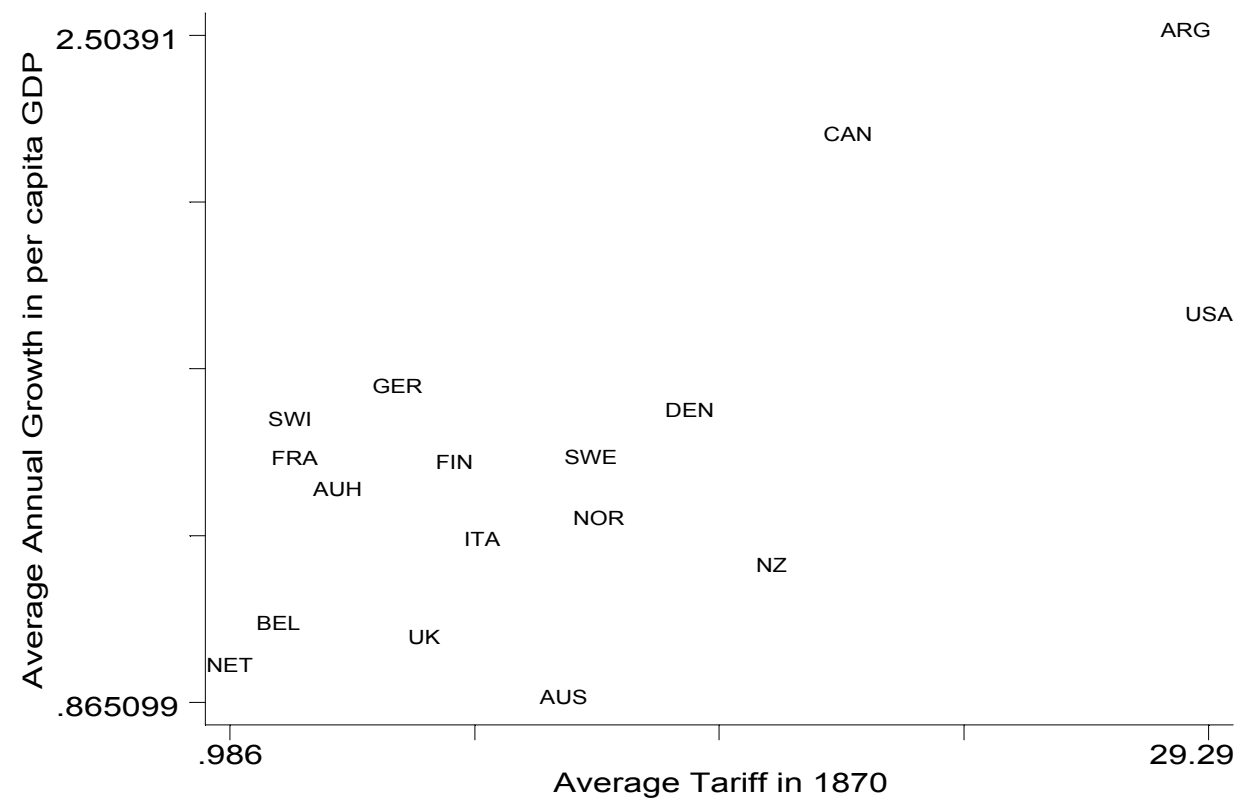

B. Extended Sample: 27 Countries

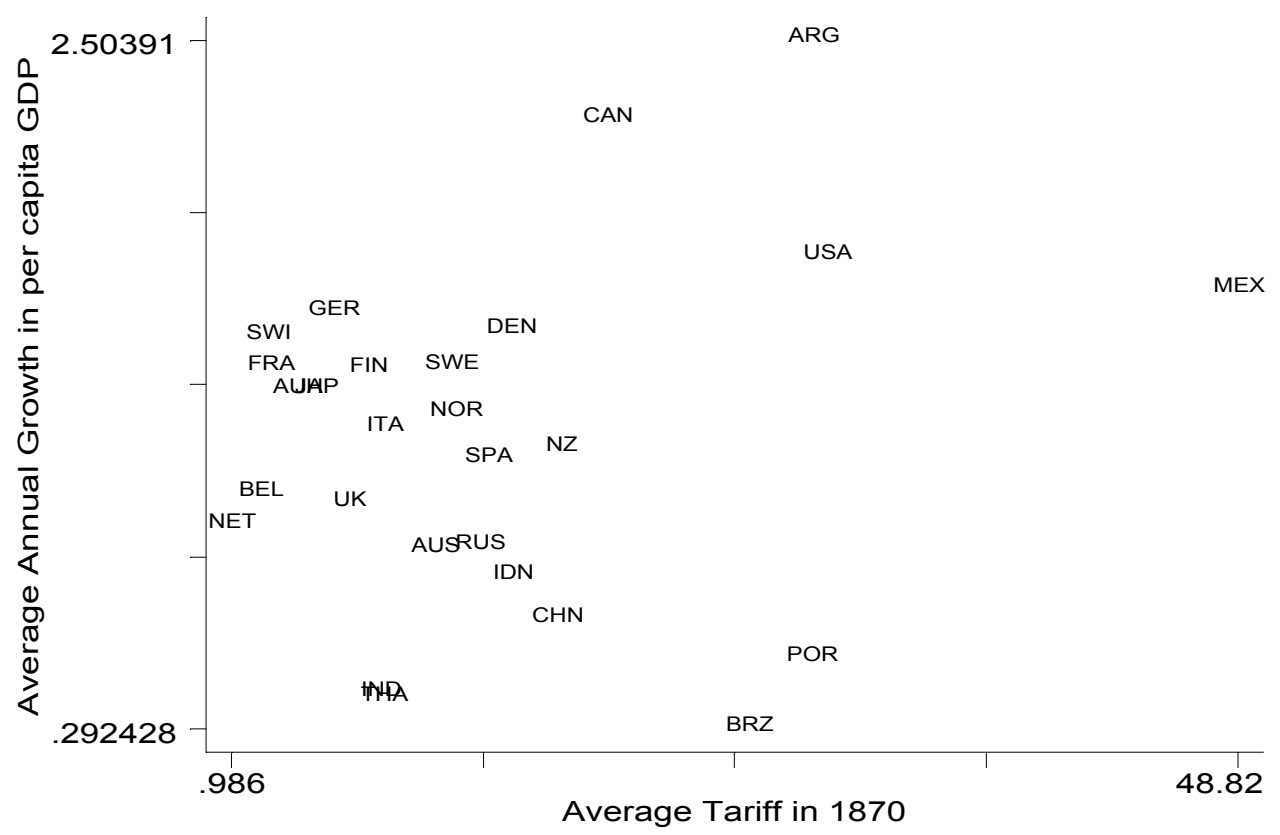


Figure 3: Growth and Political Institutions, 1870-1913

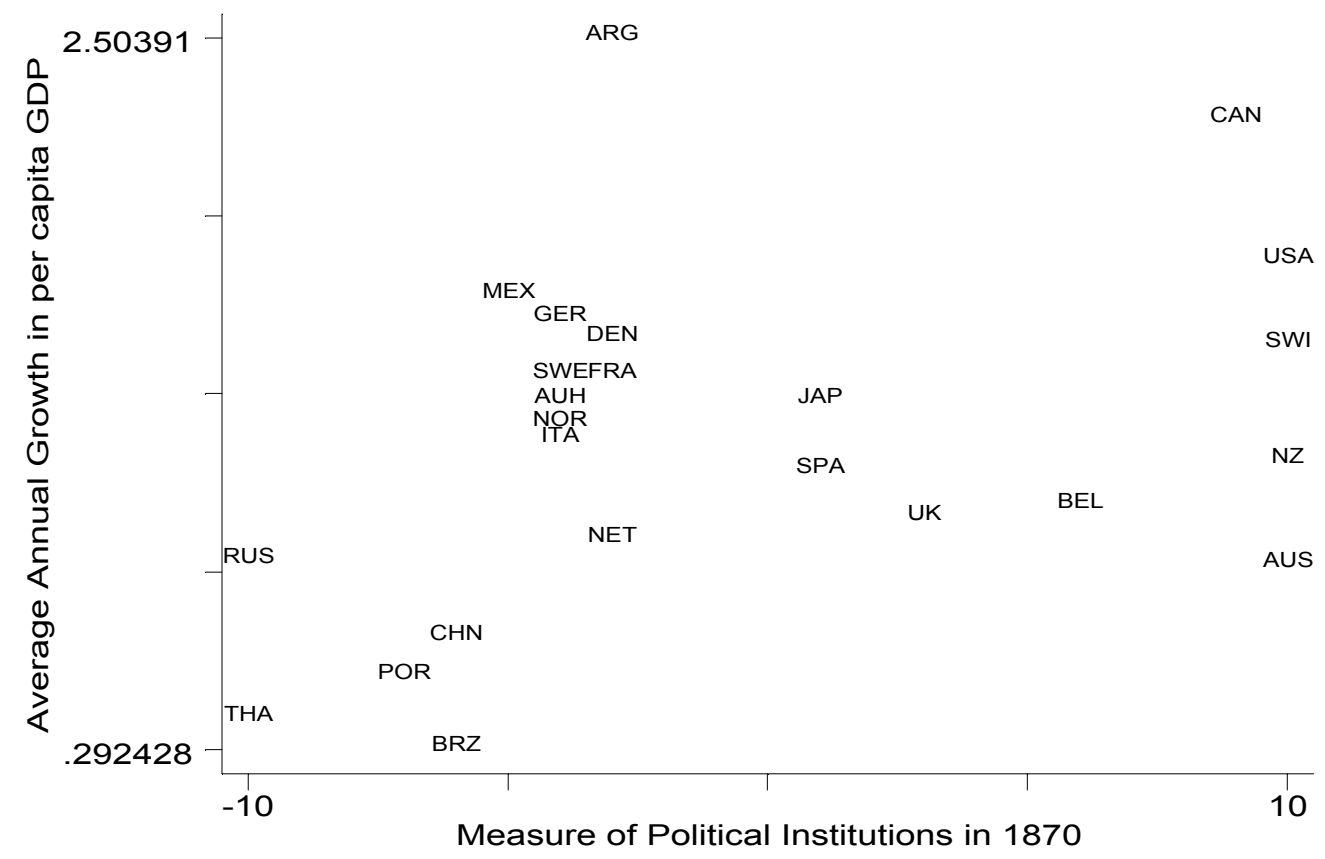

Figure 4: Growth and Initial Share of Employment in Agriculture, 1870-1913

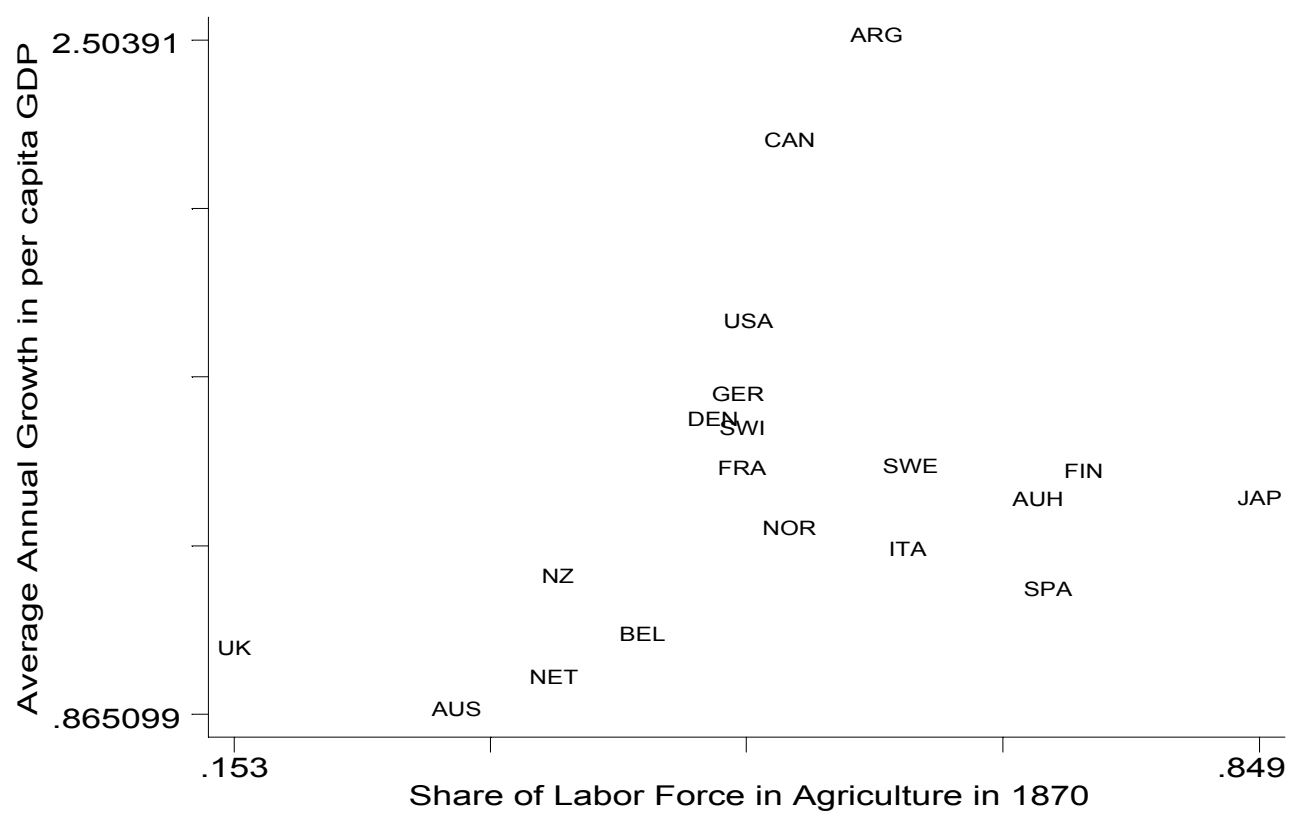


Figure 5: Growth and Change in Employment in Agriculture, 1870-1913

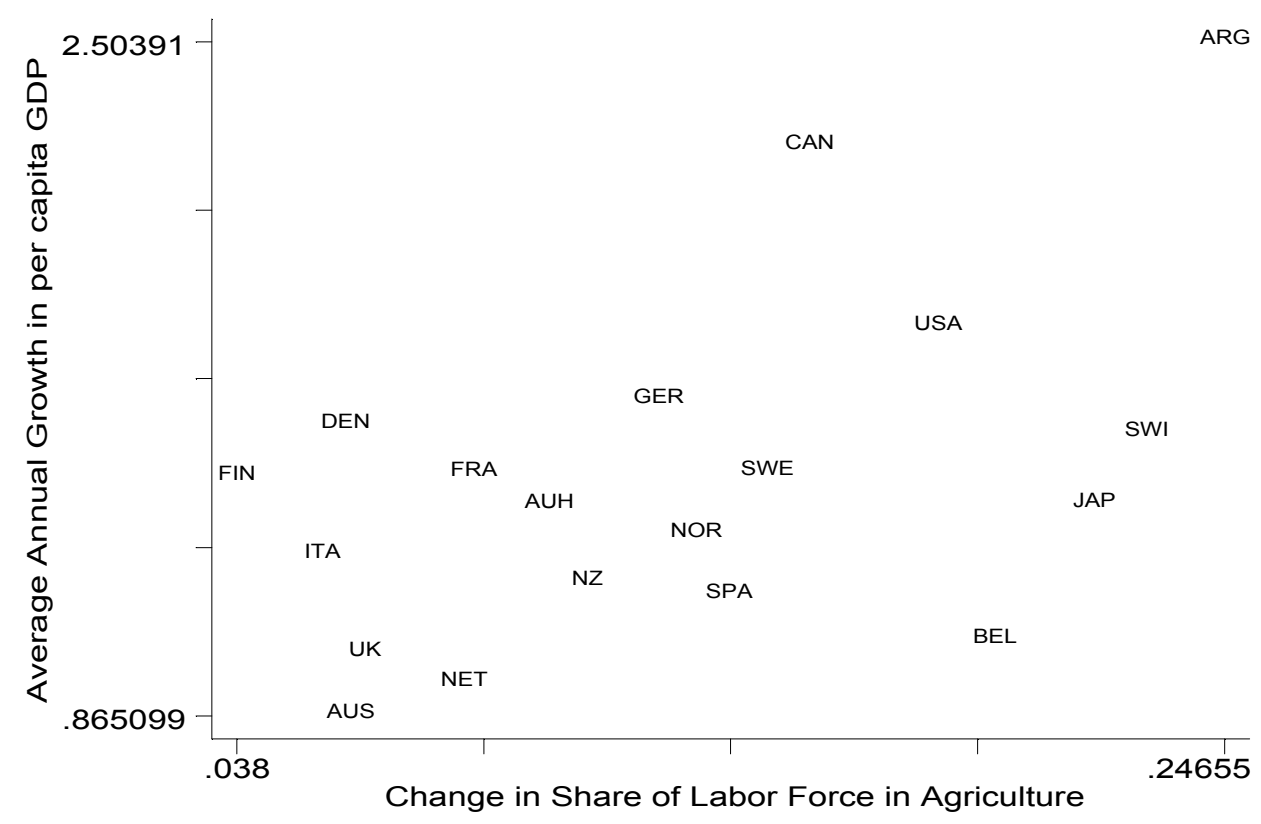

Figure 6: Growth and Change in Employment in Industry, 1870-1913

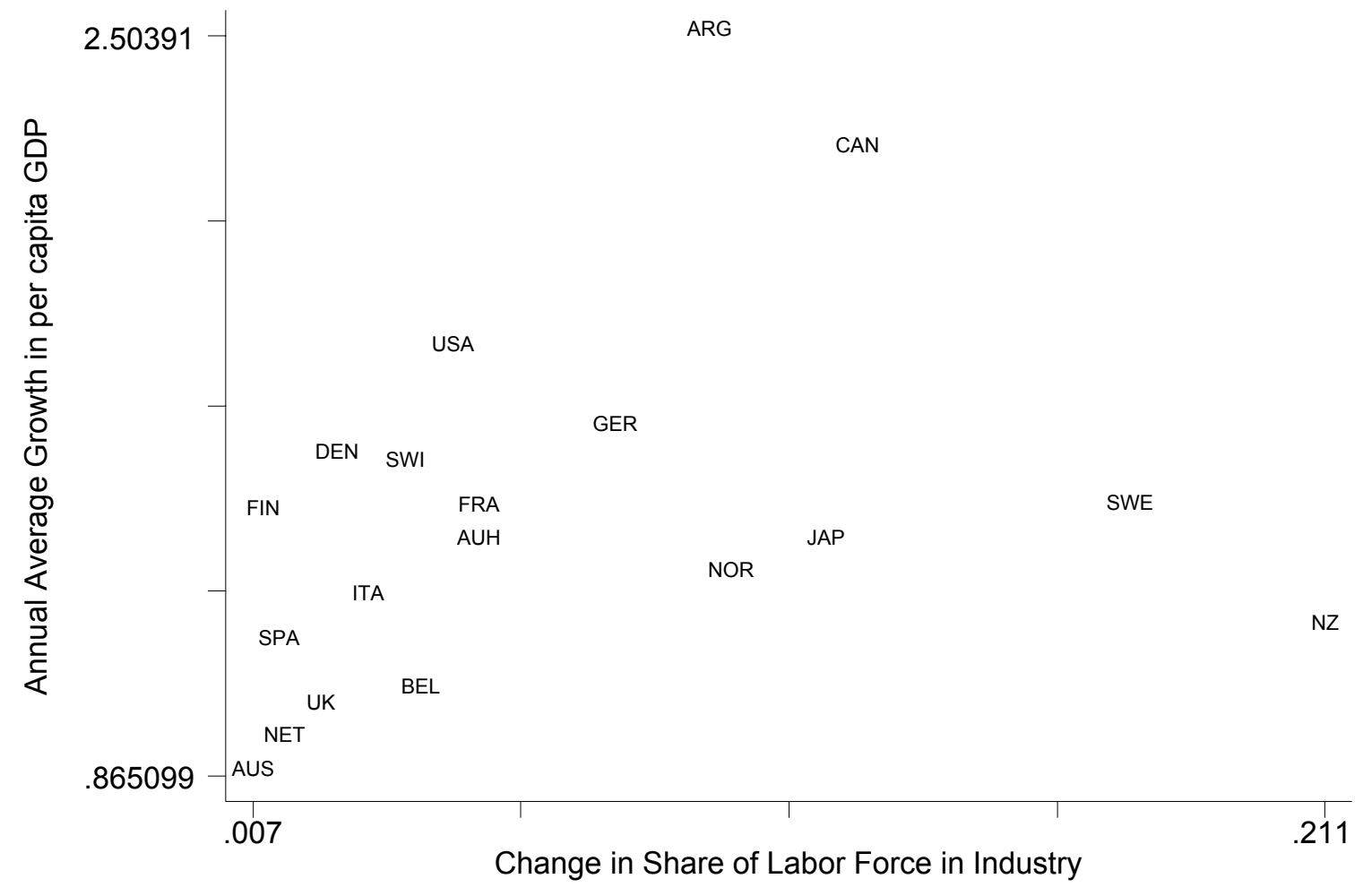

